\title{
NOTIONS OF TEACHERS IN VOCATIONAL EDUCATION ABOUT PURPOSEFULNESS
}

\author{
Inese Jurgena \\ Riga Teacher Training and Educational Management Academy, Latvia \\ Dagnija Cedere \\ Riga Teacher Training and Educational Management Academy, Latvia \\ Sarmīte Grase \\ Valmiera Vocational School, Latvia, Latvia
}

\begin{abstract}
One of the strategic aims in the development of vocational schools is teachers' purposeful professional activity. The aim of the article is to analyse notions of teachers of vocational schools about the importance of purposefulness in the life activity of pedagogues. Different research methods are used in the article: analysis of research literature, teachers' surveys. The study resulted in finding out the factors promoting purposefulness: the necessity to achieve the aim, the apprehension and setting of the aim, the selection of means for attaining the aim, application of the means corresponding to the situation leading to the achievement of the aim and implementation of a concrete action plan. The authors conclude that there exists the interconnection between teachers' purposefulness and the formation of learners' purposefulness.
\end{abstract}

Keywords: purposefulness, teachers' notions, vocational education.

\section{Introduction}

Vital reforms have been implemented in the system of vocational education since Latvia's regaining of national independence. One of the strategic aims of vocational education is the increase of its quality and competitiveness. Higher demands are set to the education of the teaching staff in vocational schools, their capacity for work and professionalism, especially in the educational field.

The studies on the personality's purposeful activity (Bernande, 2014; Katāne, Kalnina, 2010) emphasise that one of the cornerstones of the success is the person's purposefulness. Therefore, teacher's intentional, purposeful action is especially important when working in a vocational school (Lucas, Spencer, Claxton, 2012; Jurgena, Gedrovics, Cedere, 2014).

Teacher's satisfaction with life, the success of the professional action depends on aims that the person has set. The aims and values are closely connected (Seligman, 2005; Locke, Latham, 1990; Augškalne, 2012; Katāne, Kalniņa, 2010; Bernande, 2014). If the professional and personal quality (character features, abilities, skills), personal achievement, competitiveness are a value for the teacher then the way how to achieve it is to set personally meaningful, intentional aims for the life action - to improve the professional education, to work out directions for the future action, etc. 
The research performed by the authors in several vocational schools of Latvia reveals that a considerable part of teachers are aware of the necessity to set aims for their life action, they are able to gain satisfaction in their professional work and are aware of the importance of their personal achievements. The research also showed that in reality there existed the interconnection between the purposefulness of teachers in vocational schools and the formation of learners' achievement. It was stated that the achievement of teachers in vocational schools was based on their life action already in youth coupled with the purposefulness. The research is based on the idea that purposefulness is the most important feature of the person's will that is expressed in the skill to set and achieve the aim. A purposeful person is able to explore and analyse his motivation and needs, to adjust his desires to his knowledge, skills, abilities and possibilities (Bernande, 2014, 18).

Teachers' notions about the importance of purposefulness in professional work as well as the teacher's skill to combine his/her desires with the skill to get on with the changes that are all around, the necessity to change oneself and to find the opportunity to promote the learners' self-realization possibilities in the modern changing environment are especially important in this context.

The aim of the research is to analyse the ideas of teachers working in vocational schools about the importance of purposefulness in professional work.

\section{Theoretical substantiation of the research}

Social psychology theories that notions are a psychic reflection of real units found in the objective world in intentional and verbalised models or images served as the theoretical and methodological basis for the research. J. P. Leyens and B. Dardenne (Leyens, Dardenne, 1996) emphasize that there are substantiations of three kinds why cognition and the notions resulting from it are to be considered the category of social psychology. They are the following:

1) they have social roots, they can develop and be supplemented as the result of social interaction;

2) they are expressed in the social environment among its members;

3) notions can develop about social units found in the objective world.

The key function of notions is the exploration, verbalisation, and generalisation of the information gained in the process of cognition in separate images or models. O. Johnson (Johnson, 1994) considers that notions are dynamic.

The notion is the image of things, phenomena, separate situations and events perceived earlier that is preserved in memory. It is the result of processing and generalisation of what has been perceived earlier. The reflection of the perceived objects in notions has a more generalised character. Notions combine the characteristic features of objects and phenomena. Thus, the notions of the teachers of vocational schools about the purposefulness develop on the basis of their experience and generalisation. Imagining means the transformation 
of notions about a familiar environment and events gained earlier into a new combination. Unprecedented, subjective images emerge as a result of the imagination; a self created and imagined world joins the world already known in the consciousness therefore the teacher as if lives in two realities- external and internal that influence his/her life. The reflection of the objective world as it is known takes place in two reciprocally connected levels. The first level is sense, perception, notions. The subject and result of the reflection of this level is the images of the surrounding world. The notion the basis of which is the perception of one particular object will be unique because it reflects the peculiar features characteristic to the particular object. The research described in the authors' article is oriented to teachers' general notions because they reflect features which many objects of this group possess. The world in the second level is depicted indirectly and in a generalised way and it is ensured by thinking. The subject and result of this process is concepts, judgments, conclusions (Vorobjovs, 2000).

\section{Methodology of research}

The research performed in academic year 2013/2014 used a questionnaire which contained questions about purposefulness in three aspects- teachers' selfexperience, the assessment of learners' purposefulness and the possibilities of improving the study process.

Teachers of five vocational schools participated in the survey (Table 1,2).

Table 1. Characteristics of respondents

\begin{tabular}{|c|l|c|c|c|c|c|c|}
\hline \multirow{2}{*}{ No School } & \multicolumn{5}{|c|}{ The number of teachers } \\
\cline { 3 - 9 } & & \multicolumn{2}{|c}{ Women } & \multicolumn{2}{c|}{ Men } & \multicolumn{2}{c|}{ Total } \\
\cline { 3 - 9 } & & 26 & 35.6 & 4 & 21.1 & 30 & 32.6 \\
\hline 1 & Valmiera Vocational School & 21 & 28.8 & 6 & 31.6 & 27 & 29.3 \\
\hline 2 & $\begin{array}{l}\text { Smiltene State Technical School - } \\
\text { vocational secondary school }\end{array}$ & 15 & 20.5 & 4 & 21.1 & 19 & 20.7 \\
\hline 3 & Limbaži Vocational School & 2 & 2.7 & 0 & 0 & 2 & 2.2 \\
\hline 4 & Jaungulbene Vocational School & 9 & 12.3 & 5 & 26.3 & 14 & 15.2 \\
\hline 5 & $\begin{array}{l}\text { Kuldiga Vocational School of } \\
\text { Technologies and Tourism }\end{array}$ & 73 & 100 & 19 & 100 & 92 & 100 \\
\hline & \multicolumn{2}{|c|}{ Total }
\end{tabular}


SOCIETY. INTEGRATION. EDUCATION. Volume II

Table 2. Respondents' distribution per age

\begin{tabular}{|c|c|c|}
\hline \multirow{2}{*}{ Age group } & \multicolumn{2}{|c|}{ Number of respondents } \\
\hline & $\mathbf{N}$ & $\%$ \\
\hline Under 39 & 27 & 29.3 \\
\hline $40-49$ & 34 & 37.0 \\
\hline $50-59$ & 19 & 20.7 \\
\hline 60 and older & 12 & 13.0 \\
\hline Total & 92 & 100.0 \\
\hline
\end{tabular}

IBM SPSS and Microsoft Excel programs were used for the processing of findings.

\section{Analysis of findings}

The analysis of findings includes the notions about the purposefulness during the schooling years preserved in the respondents' memory and the assessment of their present learners' purposefulness.

Teachers remember and assess their academic achievement as good; besides, the achievement in special and general subjects on the whole does not differ essentially. However, more teachers (7.6\%) assess as excellent the academic achievement in special subjects and only $2.2 \%$ give excellent for general subjects. Majority of respondents (56.5\%) have consciously promoted their development during the secondary education, $21.7 \%$ already during the basic education and $12 \%$ only during the higher education stage. However, there is no significant connection between academic achievement and the time during which conscious advancement towards some set aim in life has taken place $\left(\chi_{\exp }^{2}=4.81<\chi_{\text {crit }}^{2}(0.05 ; 6)=12.59 ; \mathrm{p}=0.57\right)$. Two answers dominate regarding the question How do you describe your learning at school? - Self actualization and Objective necessity (Fig. 1).

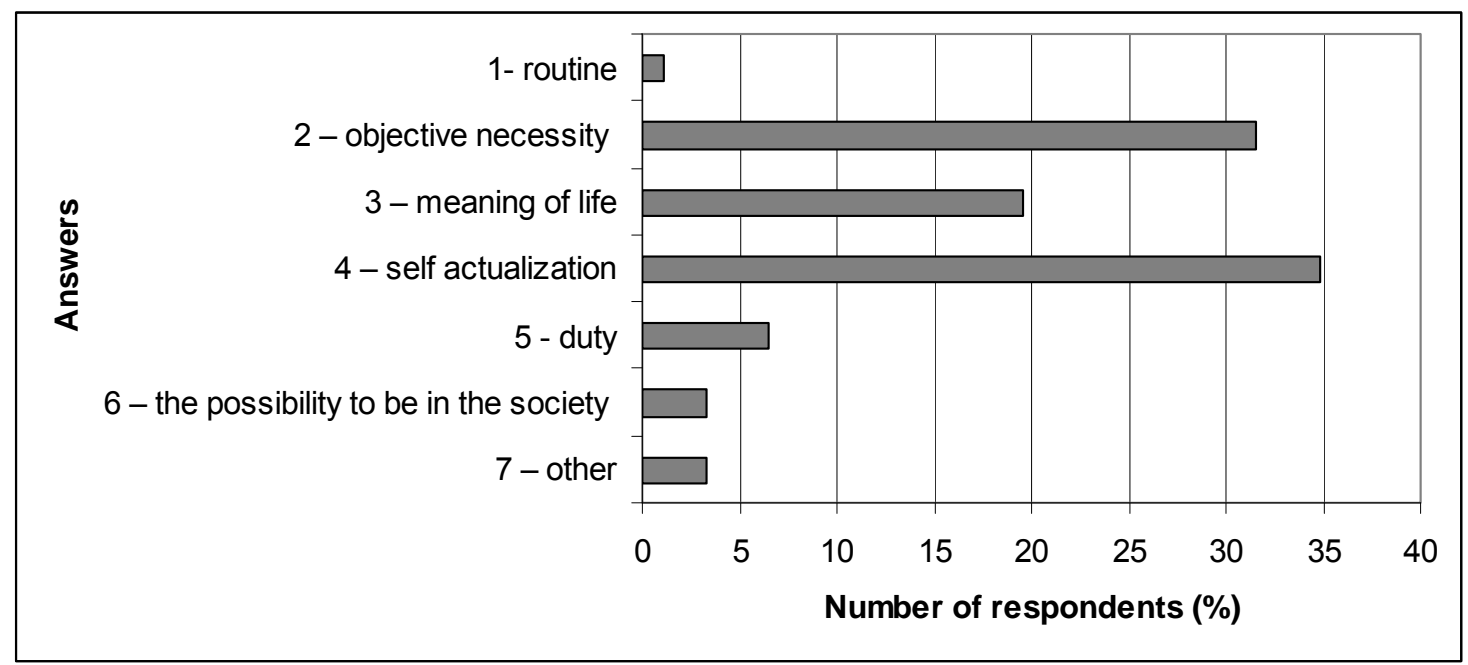

Figure 1. How do you describe your learning at school? 
Teachers consider that awareness of the aim, diligence and willpower helped them succeed at school $(77.2 \%)$ and they paid less importance to the sense of competition $(8.7 \%)$. Laziness is mentioned as the main disturbing factor $(40.2 \%)$.

Majority of respondents formulate the aim of their life during the schooling years as learning to acquire a profession in the future, to achieve good results and to gain self actualization (78.3\%), however, $6.5 \%$ of teachers admit that their key aim at that time at school had been the enjoyment of life and broadening the circle of friends.

Assessing their learners the teachers consider that many of them start comprehending their aim of aim relatively late because many of them still do not have a clear aim- this is the opinion expressed by $42.4 \%$ of the surveyed teachers.

$80.4 \%$ of respondents have given a positive answer to the question Can parents influence the learner's decision to discontinue the acquisition of the profession? The teacher's role is assessed less highly - 37\% of respondents consider that a teacher cannot influence the decision of such learners. Majority of respondents $(57.5 \%)$ claim that the learner's decision to continue learning or to drop school can be influenced both by the parents and the teachers; at the same time $13 \%$ deny both the parents and teachers' impact (Table 3 ).

Table 3. Can parents and teachers influence the learner's decision to discontinue the acquisition of the profession and to leave school?

\begin{tabular}{|c|c|c|c|}
\hline \multirow{2}{*}{ No. } & \multicolumn{2}{|c|}{ Assessment of the impact (+/- ) } & Number of respondents (\%) \\
\cline { 2 - 4 } & Parents' influence & Teacher's influence & \\
\hline 1. & + & + & 56.5 \\
\hline 2. & + & - & 23.9 \\
\hline 3. & - & + & 6.5 \\
\hline 4. & - & - & 13.0 \\
\hline
\end{tabular}

The teacher's impact on the learners' decision is more admitted by those teachers who themselves had been more purposeful during their school years. Dividing the respondents per age groups it is possible to conclude that actually there are no statistically significant differences between the opinions expressed by the experienced teachers and their younger colleagues. Statistically significant differences can be observed only in the assessment of the teacher's impact where at the level of significance $\alpha=0.05$ there exists a significant correlation $\left(r=0.264>r_{\text {crit }}=0.196\right)$ among the features. Such a finding indicates that younger teachers value the educational work higher that older teachers. The structure of the questionnaire unfortunately does not allow judging about the 
reasons why more than a third of the teachers value their impact on the learners' learning so low.

On the whole there are no significant differences concerning answers provided by teachers of both genders except the answers to the question Why do young people decide to study in the vocational school? $\left[\chi_{\exp }^{2}=17.38>\chi_{\text {crit }}^{2}\right.$ $(0.05 ; 4)=9.49 ; \mathrm{p}=0.002] .57 .5 \%$ of female respondents mention the possibility offered by the vocational secondary school to obtain simultaneously the certificate on secondary education and to master the profession as the key criterion for this choice; such an answer was given only by $2.6 \%$ of male teachers; the distribution of other answers given by male respondents is relatively even.

Almost all respondents (99\%) consider that vocational education programs ensure the possibility to acquire general knowledge and skills and they also ensure qualitative acquisition of the profession.

The suggestion to introduce remuneration for work during the study practice so that the graduates of vocational schools were able to integrate better in the labour market dominates in the aspect of improving the study process. Such a view is expressed by almost $40 \%$ of respondents, besides there is so significant difference depending on the respondents' gender (Fig. 2).

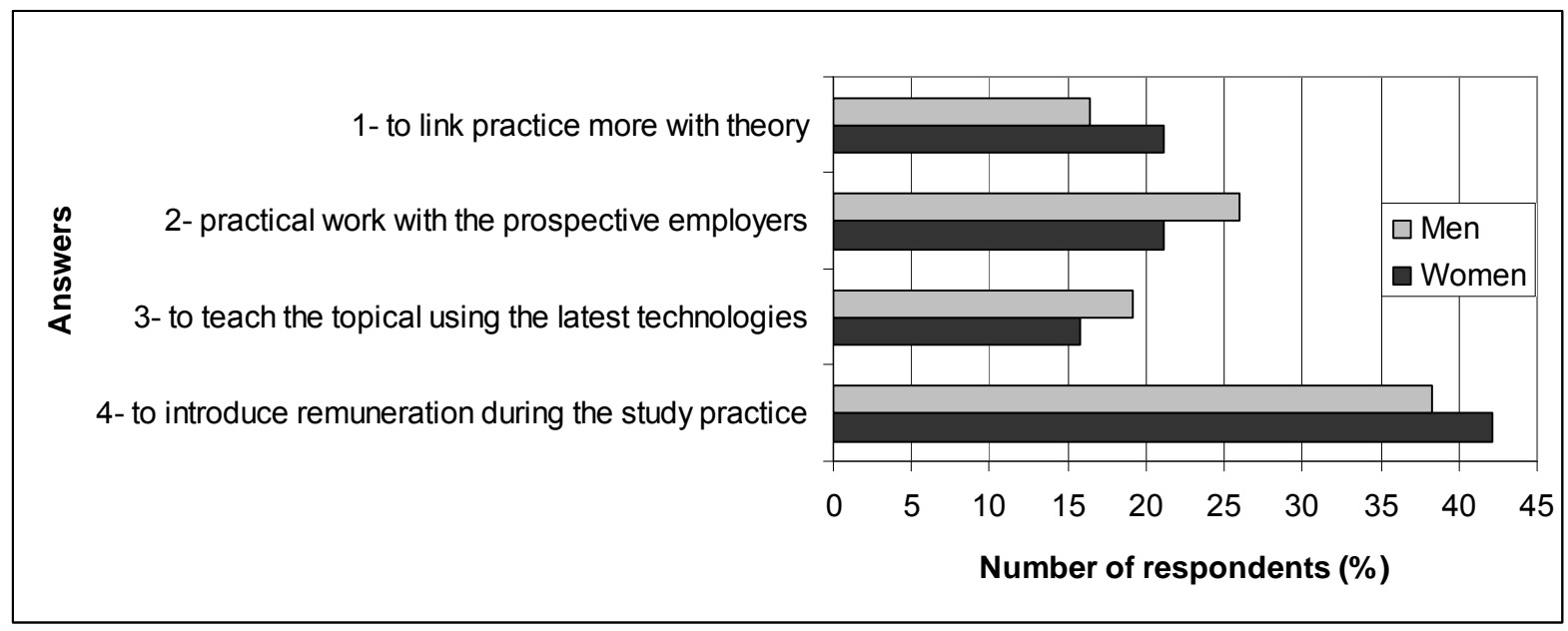

Figure 2. What should be changed in or added to the program so that the learner after the acquisition of the profession was able to integrate in the labour market?

Analyzing the factors that according to respondents' views are decisive for the acquisition of vocational education the diversity of opinions can be seen. However, a relatively great number of teachers consider that the main motivating factor is the learner's interest in the chosen speciality (40\%) and the state support (30\%). The number of teachers who connect learning motivation with a good salary in the future or a prestigious work is smaller $(12 \%$ and $2 \%$ respectively). 
Evaluating teachers' notions about what mainly does not allow the learners to reach better academic achievements a strongly pronounced dominant factor stands out- the laziness which has been mentioned by almost $60 \%$ of respondents. Assessment of the opinions expressed by the respondents allows concluding that unsuccessful cooperation with the teacher cannot be considered a factor disturbing the learning because it was mentioned only by $2.2 \%$ of the surveyed teachers (Fig. 3).

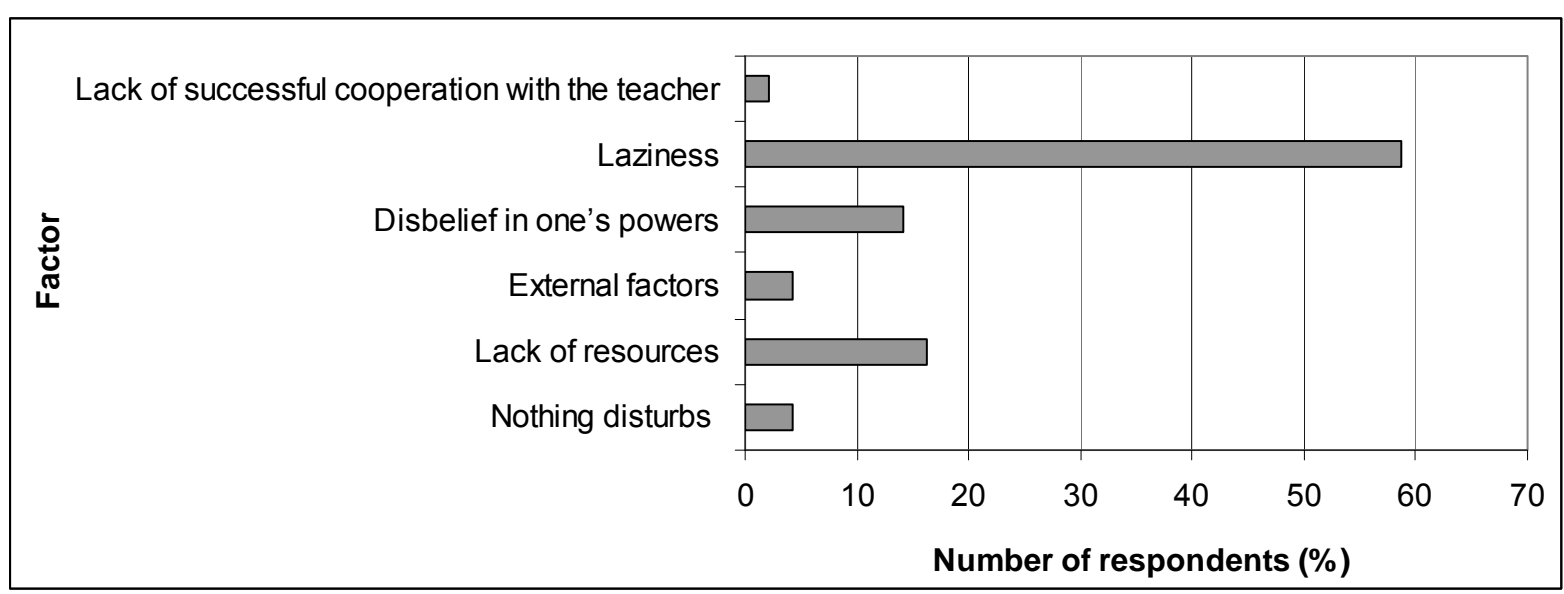

Figure 3. Factors influencing or disturbing learners' abilities to reach better academic achievement

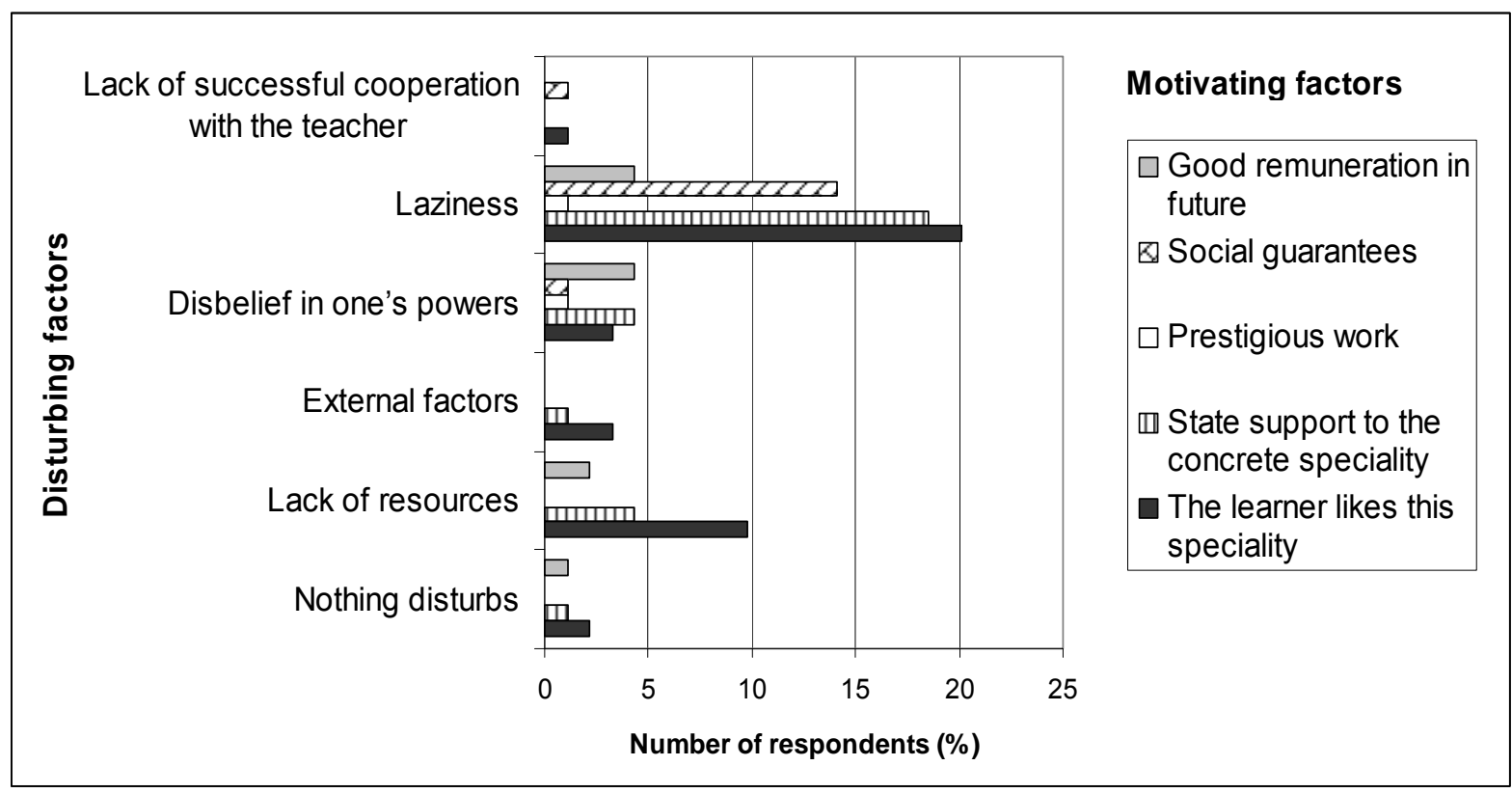

Figure 4. Reciprocal influence of factors disturbing and motivating learners' learning

Evaluating the connection between the factors motivating learning and those disturbing learning (Fig. 4), it is obvious that laziness which dominates pronouncedly $(58.7 \%)$ is to be connected with learners' reliance upon the possible state guarantees. The greatest part of those teachers who consider that learners choose to study in the vocational school not because of pragmatic 
considerations but because they like the chosen profession also admit that laziness is a frequent feature among the learners. Such reciprocity of factors indicates that insufficient learners' purposefulness in vocational schools is a rather spread phenomenon.

The research revealed that the formation of purposefulness in the notions of the teachers of vocational schools is a topical issue.

\section{Conclusions}

The basis of the formation of purposefulness is the aim of the personality's life action the function of which is the self-developed plan of the life. The purposefulness and the advance towards achievements and success in the life activity of the teachers of vocational schools are based on the self-experience of teachers and it influences the formation of learners' purposefulness.

Factors promoting their purposefulness were uncovered in the notions of the teachers of vocational schools: the necessity to achieve the aim, the apprehension and setting of the aim, the selection of means for attaining the aim, application of the means corresponding to the situation leading to the achievement of the aim and implementation of a concrete action plan. The research found out that achievements in one's life action according to the assessment of the vocational teachers are connected with good academic achievement in those school subjects that are related to the future life plans already in the school years. Laziness, which is a subjective internal factor of the personality, is singled out as a significant disturbing factor for the achievement.

The notions of the teachers of vocational schools about the learners' purposefulness indicated that it was important in the formation of the purposefulness that the learner realized the learning process as meaningful for $\mathrm{him} /$ herself in which learning acquired a personal meaning.

The educational work in vocational schools faces problems concerning the improvement of learners' purposefulness as the personal quality. Younger teachers are more positively oriented towards cooperation in developing the learners' purposefulness in the pedagogical process than the older teachers.

\section{References}

Augškalne, I. (2012). Profesionālo skolu audzēkņu pasaules uzskata izpēte (Exploration of the world outlook of vocational learners). Promocijas darba kopsavilkums (Summary of Doctoral thesis). Jelgava: LLU.

Bernande, M. (2014). Jauniešu mērķtiecības un sasniegumu veidošanās mijsakarības dzìvesdarbība (Coherence of young people's purposefulness and the formation of achievements in the life action). Promocijas darbs (Doctoral thesis). Riga: RPIVA.

Johnson, O. G. (1994). Concept learning. In: Rymond J. Corsini (ed.), Encyclopaedia of Psychology. New York: John Wiley\&Sons, 1, 248-285.

Locke, E. A., Latham, G. P. A. (1990). Theory of Goal Setting and Task Performance. New York: Prentice Hall. 
Lucas, B., Spencer, E., Claxton, G. (2012). How to teach Vocational Education: A theory of Vocational pedagogy. Winchester: Centre for Real-World Learning.

Leyens, J.-P., Dardenne, B. (1996). Basic concepts and Approaches in social cognition. In: W. Hevstone, W. Stroebe, G. M. Stephenson (eds.) (1996). Introduction to Social psychology: A European perspective. (pp. 110 - 134). Oxford: Blackwell Publisher.

Maslow, A. H. (1954). Motivation and Personality. New York: Happer.

Jurgena, I., Gedrovics, J., Cedere, D. (2014). Students' views on the professional career opportunities. Engineering for Rural Development. In: Proceedings of the 13th International scientific conference „Engineering for rural development” (pp. 522-528). Jelgava: LLU. Available at:

http://www.tf.llu.lv/conference/proceedings2014/Papers/89_Jurgena_I.pdf.

Katane, I., Kalnina, I. (2010). Development of Students' Personality Competitiveness within the Environment of Non-Formal Commercial Education. Jelgava: LLU.

Seligman, M. E. P., et al. (2005). Positive Psychology Progress. American Psychologist, 5, 410-421.

Vorobjovs, A. (2000). Vispārīgā psihologija (General psychology). Rīga: Izglìtības soḷi. 